\title{
Pengaruh latihan squat menggunakan free weight dan gym machine terhadap kekuatan, power, dan hypertrophy otot
}

\author{
Lia Karina Mansur *, Joko Pekik Irianto, Mansur Mansur \\ Program Studi Ilmu Keolahragaan, Program Pascasarjana, Universitas Negeri Yogyakarta. \\ Jalan Colombo No. 1, Karangmalang, Yogyakarta 55281, Indonesia. \\ * Corresponding Author. Email: karinalia_02@yahoo.com \\ Received: 23 October 2017; Revised: 12 March 2018; Accepted: 15 November 2018
}

\begin{abstract}
Abstrak
Penelitian ini bertujuan untuk menguji pengaruh latihan squat menggunakan free weight dan gym machine terhadap kekuatan, power, dan hypertrophy otot; dan menguji perbedaan pengaruh latihan squat menggunakan free weight dan gym machine terhadap kekuatan, power, dan hypertrophy otot. Penelitian ini adalah penelitian eksperimen dengan desain two group pretest-posttest design. Sampel dalam penelitian ini dipilih berdasarkan teknik random sampling berjumlah 32 orang. Instrumen untuk mengukur kekuatan menggunakan back and leg dynamometer merk Takei buatan Jepang. Instrumen untuk mengukur power menggunakan Jump Duration of Fright (JDF) seri TKK 5114 buatan Jepang, satuan sentimeter. Instrumen untuk mengukur lingkar otot paha menggunakan meteran dengan satuan sentimeter. Teknik analisis data yang digunakan adalah analisis multivariat pada taraf signifikansi $\alpha=$ 0,05 . Hasil penelitian menunjukkan bahwa (1) ada pengaruh yang signifikan latihan squat menggunakan free weight terhadap kekuatan, power, dan hypertrophy otot, (2) ada pengaruh yang signifikan latihan squat menggunakan gym machine terhadap kekuatan, power, dan hypertrophy otot, dan (3) ada perbedaan yang signifikan antara latihan squat menggunakan free weight dan latihan squat menggunakan gym machine terhadap kekuatan, power, dan hypertrophy otot. Persentase kenaikan nilai pretest dan posttest kekuatan, power, dan hypertrophy otot menunjukkan kelompok latihan squat menggunakan free weight lebih baik daripada kelompok gym machine.
\end{abstract}

Kata Kunci: latihan squat free weight, latihan squat gymmachine, kekuatan, power, hipertrofi otot

\section{The influence of squat practice using free weight and gym machine on the strength, the muscle and the hypertrophy of the muscle}

\begin{abstract}
The study aims at testing the influence of squat training using free weight and gym machine on the strength, the power and the hypertrophy of the muscle and at testing the differences between the influence of squat training using free weight and the influence of squat training using gym machine on the strength, the power and the hypertrophy of the muscle. The study is an experiment with two group pre-test-post-test design. Then, the samples for the study were selected based on the random sampling technique and the total number of the respondents was 32 people. The instrument for measuring the strength of the muscle was back and leg dynamometer Takei made in Japan while the instrument for measuring the power of the muscle was Jump Duration of Fright (JDF) series TKK 5114 made in Japan with centimetre unit. Furthermore, the instrument for measuring the circle of the tight muscle was a gauge with centimetre unit. The results of the study show that: (1) the squat training using the free weight has significant influence on the strength, the power and the hypertrophy of the muscle; (2) the squat training using the gym machine has significant influence on the strength, the power and the hypertrophy of the muscle; and (3) there has been significant difference between the squat training using the free weight and the squat training using the gym machine on the strength, the power and the hypertrophy of the muscle. The increasing percentage from the pre-test score into the post-test score in the strength, the power and the hypertrophy of the muscle shows that the training group that performs the squat training using the free weight has better performance than the group that performs the squat training using the gym machine.
\end{abstract}


Jurnal Keolahragaan 6 (2), 2018 - 151

Lia Karina Mansur, Joko Pekik Irianto, Mansur Mansur

Keywords: squat training using free weight, squat training using gym machine, strength of the muscle, power of the muscle, hypertrophy of the muscle.

How to Cite: Mansur, L., Irianto, J., \& Mansur, M. (2018). Pengaruh latihan squat menggunakan free weight dan gym machine terhadap kekuatan, power, dan hypertrophy otot. Jurnal Keolahragaan, 6(2), 150-161. doi:https://doi.org/10.21831/jk.v6i2.16516

https://doi.org/10.21831/jk.v6i2.16516

\section{PENDAHULUAN}

Kesadaran berolahraga semakin hari semakin meningkat, salah satu cara yang sering dilakukan adalah dengan melakukan aktivitas fisik atau berolahraga. Berbagai motif orang melakukan olahraga di antaranya adalah menjaga kebugaran, meningkatkan fisik, atau memperoleh prestasi sesuai dengan cabang olahraga yang diminati. Olahraga merupakan suatu bentuk aktivitas fisik menurut cara dan aturan tertentu dengan tujuan meningkatkan efisiensi fungsi tubuh yang hasil akhirnya adalah meningkatkan kebugaran jasmani atau kondisi fisik yang akan berpengaruh pula pada peningkatan prestasi pada cabang olahraga.

Prestasi olahraga merupakan aktualisasi dari berbagai unsur, seperti kondisi fisik, kemampuan teknik, penguasaan taktik, dan kematangan mental. Jadi dapat dikatakan bahwa kondisi fisik merupakan komponen mendasar dalam usaha mencapai sebuah prestasi yang diinginkan. Keberhasilan dalam latihan tidak semata-mata ditentukan oleh potensi genetik atau bakat, namun fokus atlet dalam pelatihan membuat perbedaan dalam pencapaian tujuannya. Sebagai contoh untuk melampaui kekuatan yang diwariskan atau potensi genetiknya, seorang atlet harus fokus pada adaptasi fisiologis dalam latihan. Secara fisiologis, olahraga dapat dijadikan wahana pemberdayaan kemampuan fungsi fisiologis seperti meningkatkan kesehatan, kebugaran, dan meningkatkan kualitas komponen kondisi fisik. Untuk memperoleh keterampilan fisik yang optimal perlu adanya sistem pembinaan yang teratur, terprogam, dan berkesinambungan serta ditempuh dengan pendekatan-pendekatan ilmiah.

Menurut Suharjana, (2013, p.18) peningkatan kemampuan kerja otot akibat latihan disebabkan perubahan fisiologis yang terjadi pada sistem neuromuscular (adaptasi sistem neuromuscular). Lebih lanjut, Sukadiyanto dan Muluk (2011,pp. 9-10) menyatakan bahwa sasaran utama latihan fisik adalah untuk meningkatkan kualitas kebugaran jasmani (energy fitness) dan kebugaran otot (muscular fitness). Fisik merupa- kan fondasi dari prestasi olahragawan, sebab teknik, taktik, dan mental akan dikembangkan dengan baik jika memiliki kualitas fisik yang baik. Kondisi fisik sangat menunjang dalam mempersiapkan latihan dan pertandingan, sehingga atlet tidak mengalami kelelahan yang berarti dan akan terhindar dari cedera yang dapat mengganggu penampilannya. Oleh karena itu, kondisi fisik sangatlah diperlukan dalam cabang olahraga.

Untuk mencapai prestasi tinggi dalam olahraga kompetitif, diperlukan kondisi fisik prima sesuai dengan kebutuhan dan tuntutan cabang olahraga. Kondisi fisik prima harus menjadi kebutuhan setiap atlet, terutama untuk cabang olahraga yang menuntut kinerja berat berdurasi lama. Banyak keuntungan yang diperoleh dari kondisi fisik prima, yaitu mudah dalam menguasai keterampilan kompleks, mengurangi risiko cedera, mempertahankan kinerja fisik, mempercepat pemulihan pasca- latihan, dan meningkatkan rasa percaya diri. Seperti diungkapkan Sajoto dalam Karyono (2011, p.2) bahwa komponen kondisi fisik meliputi kekuatan (strength), kecepatan (speed), daya tahan (endurance), daya ledak otot (muscular explosive power), kelincahan (agility), keseimbangan (balance), kelentukan (flexibility), dan koordinasi (coordination). Semua komponen kondisi fisik harus dapat dikembangkan guna menunjang prestasi atlet.

Bompa dan Buzzichelli (2015, p.19) mengatakan, Understanding muscle adaptation and its dependence on load and training method makes it easier to grasp why certain types of load, exercise, or training method are preferred for some sports and not for others. Success in strength training depends on knowing the types of strength and how to develop them, as well as the types of contraction and which are best for a given sport.

Dalam pelatihan olahraga sistem biologis dan jaringan dikondisikan dengan menerapkan tuntutan fisik yang semakin berat berdasarkan perkembangan kondisi fisik atlet. Untuk mencapai tujuan tersebut diperlukan pendekatan pelatihan secara tepat. Dalam terminologi 
Jurnal Keolahragaan 6 (2), 2018 - 152

Lia Karina Mansur, Joko Pekik Irianto, Mansur Mansur

pelatihan lazim disebut dengan metode pelatihan. Menurut Oxford Dictionary metode adalah salah satu bentuk prosedur untuk mencapai atau mendekati sesuatu, terutama yang sistematis. Training (pelatihan) adalah tindakan mengajarkan keterampilan tertentu atau jenis perilaku seseorang. Singh (2012, p.26) menyatakan latihan merupakan proses dasar persiapan untuk kinerja yang lebih tinggi yang prosesnya dirancang untuk mengembangkan kemampuan motorik dan psikologis untuk meningkatkan kemampuan seseorang. Latihan adalah suatu aktivitas olahraga yang dilakukan secara sistematis dalam waktu yang lama ditingkatkan secara progresif dan individual mengarah kepada ciri-ciri fungsi fisiologis dan psikologis untuk mencapai sasaran yang telah ditentukan. Dengan metode pelatihan yang tepat, tubuh akan mengalami adaptasi berupa peningkatan kemampuan fungsional tubuh sehingga mampu melakukan kinerja berat dalam waktu relatif lama.

Adaptasi fungsional otot telah didokumentasikan dengan baik oleh banyak peneliti, begitu juga strategi atau metode pengembangan kualitas otot telah dipublikasikan melalui berbagai laporan dengan jenis kegiatan olahraga yang berbeda. Pengaruh latihan bergantung pada intensitas dan volume latihan. Kegagalan untuk memenuhi nilai ambang batas minimal dapat mengakibatkan kurangnya efek latihan, sementara terlalu berat dapat menyebabkan overtraining dan berpengaruh negatif terhadap kondisi fisik atlet. Dalam hal ini, atlet kurang terlatih relatif lebih mudah meningkat/adaptasi positif ketika mendapat perlakuan latihan (Chandler \& Brown, 2008,), sebaliknya, atlet terlatih dibutuhkan usaha luar bisa untuk mendapakan pengaruh sebagaimana atlet kurang terlatih yaitu dengan memodifikasi intensitas, frekuensi, volume, recovery, dan densitas latihan.

Setiap melakukan aktivitas fisik khususnya berolahraga selalu dihadapkan kemungkinan cedera sehingga akan berdampak pada gangguan aktivitas fisik, psikis, dan prestasi. Salah satu anggota tubuh yang paling sering mengalami cedera adalah pada bagian kaki. Kaki merupakan bantalan berat seluruh tubuh, berada di bawah tekanan yang luar biasa. Dalam banyak olahraga, kaki menyerap geseran dan pemuatan gaya sangat besar, kadang-kadang mencapai lebih dari lima kali berat badan. Lin, Hiller, \& de Bie (2010, p.22) mengatakan studi yang mengkaji tentang cedera ankle ada 24 dari 70 kajian dengan $22 \%$ cedera olahraga adalah cedera ankle dengan rasio sprain dan fraktur adalah 8:1. Cedera ini cende- rung meningkat ketika terlibat gerakan eksplosif yang semakin sulit. Kompetisi tingkat atas membutuhkan peningkatan pengkondisian neuromuskuler karena atlet harus begerak vertikal, lateral, linear, lebih tepat, eksplosif, dan reaktif.

Cedera pada saat berolahraga juga banyak terjadi di bagian ligamen. Anterior Cruciate Ligament (ACL) adalah ligamen di dalam sendi yang menjaga kestabilan sendi lutut yang rawan terjadi pada olahraga high-impact, seperti sepak bola, futsal, tenis, badminton, bola basket, dan olahraga bela diri (Zein, 2013, p.111). Dalam fungsinya yang normal, $A C L$ dapat menangani kekuatan yang besar dengan sedikit atau tanpa masalah. Meskipun demikian, jika lutut menerima kekuatan yang besar dan otot tidak dapat membantu meredam tekanan, $A C L$ akan mengambil alih semua beban, dan memungkinkan terjadinya kerobekan. Ada kemungkinan bahwa sebagian besar cedera ini hasil dari ketidakstabilan sendi akibat kelelahan musculature. Relevansi kelelahan stabilitas sendi dibuktikan dengan hubungan antara kontrol postural dan daya tahan isokinetik kelompok otot lutut. Sebagian besar atlet menjaga dan meningkatkan kondisi fisik hanya dengan mengambil bagian dalam olahraga yang mereka pilih, belum disertai dengan latihan yang melibatkan analisis gerak yang mensyaratinya. Sementara itu, kompetitisi tingkat atas membutuhkan persyaratan core muscle, kekuatan maksimal otot tungkai, stabilitas, keseimbangan, kecekatan lateralis, lompatan vertikal, dan waktu reaksi yang lebih tinggi. Kualitas ini dapat ditingkatkan melalui kombinasi pelatihan beban.

Komponen biomotor satu dengan yang lainnya saling berhubungan, dan setiap komponennya memerlukan latihan tersendiri. Dari uraian di atas dapat disimpulkan bagaimana pentingnya otot anggota tubuh bagian bawah untuk menopang seluruh anggota tubuh dan risiko cedera yang sering terjadi. Pada saat seorang atlet melakukan suatu gerakan seperti berlari dan melompat bahkan otot bagian bawah akan menopang tiga kali berat badannya, dan hal tersebut akan membutuhkan kekuatan dan power yang merupakan gabungan antara kekuatan dan kecepatan yang baik. Di samping itu, telah disebutkan di atas bahwa kekuatan atau power merupakan kondisi fisik dasar. Berdasakan dari hal tersebut pengembangan atau peningkatan kekuatan dan power sangat penting untuk dilakukan. Kekuatan merupakan kemampuan otot atau sekelompok otot untuk berkontraksi baik isotonik, isometrik, eksentrik, dan isokinetik 
Jurnal Keolahragaan 6 (2), 2018 - 153

Lia Karina Mansur, Joko Pekik Irianto, Mansur Mansur

dengan tujuan membangkitkan ketegangan terhadap suatu ketahanan dalam satu kerja. Di sisi lain, power is the rate at which work is performed or the rate of the transformation of metabolic potential energy to work and/or heat (Ismoko \& Sukoco, 2013, p.4).

Ada beberapa cara untuk meningkatkan komponen kondisi fisik salah satunya dengan latihan beban (weight training). Latihan beban (weight training) adalah latihan yang dilakukan secara sistematis dengan menggunakan beban sebagai alat untuk menambah kekuatan fungsi otot guna mencapai tujuan seperti memperbaiki kondisi fisik, mencegah terjadinya cedera, atau untuk tujuan kesehatan. Untuk mencapai tujuan latihan atau fitness secara optimal, perlu diketahui prinsip-prinsip dasar dalam latihan fitness yang memiliki peranan yang penting terhadap aspek fisiologis maupun psikologis. Latihan beban yang tepat hendaknya menerapkan prinsip-prinsip dasar latihan beban guna mencapai hasil yang maksimal bagi seseorang. Suharjana, (2013, p.18) menyatakan bahwa perubahan akibat latihan antara lain karena terjadinya hypertrophy otot. Sucipto dan Widiyanto (2016, p.112) berpendapat bahwa weight training berbeda dengan weight lifting. Peningkatan ukuran otot menyebabkan kontraksi otot lebih kuat (power meningkat). Seiring dengan adaptasi fisiologis, latihan juga menyebabkan adaptasi pada beberapa unsur fisik. Lebih lanjut, Suharjana (2013, p.20) menyatakan latihan selain membangun kekuatan, latihan juga dapat mengembangkan kemampuan unsur kondisi fisik atau kemampuan biomotor yang lain, misalnya daya tahan otot, kecepatan, dan explosive power. Hal tersebut dikarenakan latihan menyebabkan pengulangan kontraksi lebih cepat.

Untuk melatih tubuh bagian bawah, ada beberapa macam bentuk latihan yang sudah diterapkan salah satunya adalah latihan squat merupakan salah satu latihan yang paling sering digunakan untuk meningkatkan kekuatan dan pengondisian (Schoenfeld, 2010, p.3497). Latihan standar yang digunakan adalah back squat karena meningkatkan kekuatan tubuh bagian bawah (Archer, et al., 2016, p.18).

Pelatih percaya bahwa latihan squat bisa membantu atlet mengurangi cedera dan meningkatkan performa. Meskipun demikian, dalam latihan ini apabila dilakukan tidak sesuai teknik akan berbahaya, yaitu mengakibatkan cedera. Di samping itu, latihan squat juga melibatkan kelompok otot besar manusia, terutama kelompok otot quadriceps, harmstring, dan gluteus- maximus. Menurut Bompa dan Harf (2009) latihan beban yang melibatkan multi joint dinilai lebih efektif dalam mengembangkan biomotor dan berimbas pada peningkatan penguasaan keterampilan dalam olahraga dibandingkan latihan single joint. Dari uraian di atas dapat disarikan bahwa squat merupakan salah satu jenis latihan beban yang sangat penting dalam meningkatkan kualitas tungkai bawah.

Dalam latihan squat terdapat dua jenis yaitu latihan dengan menggunakan beban bebas dan menggunakan mesin. Parrish (2014), menyatakan bahwa free weight melibatkan penggunaan dumbbell, barbell, atau benda tertimbang lainnya yang digunakan dalam berbagai teknik pelatihan. Hal ini disebut free weight karena beratnya yang tidak tetap, yang berarti bahwa orang yang memegang harus menstabilkan sendiri. Stabilisasi diperlukan karena free weight memerlukan bantuan orang lain untuk mengontrol beban. Contoh latihan free weight yaitu dumbbell chest press, bent over row, dan barbell back squat. Free weight membutuhkan beberapa kelompok otot untuk mengangkat beban berat, menjaga beban agar tetap stabil, dan membutuhkan orang lain untuk menjaga keseimbangan selama pelaksanaan. Lebih lanjut Parrish (2014), menambahkan bahwa gym machine ideal bagi para pemula, orang-orang dengan cedera tertentu, atau orang lanjut usia. Gym machine dirancang untuk menyederhanakan gerakan dan efektif dalam mengisolasi kelompok otot yang berbeda karena stabilisasi otot dikeluarkan dari pelatihan tersebut. Sebagai contoh, pada bench press machine (seperti machine smith), bar mengikuti jalur yang sama pada arah atas dan bawah. Meskipun demikian, apabila seseorang melakukan bench press dengan menggunakan free weight, kekuatan lebih diperlukan untuk mengangkat beban berat secara horizontal maupun vertikal dan menjaga badan agar tetap seimbang. Hal ini dapat menyebabkan kelelahan akibat menstabilkan otot.

Pelatihan menggunakan free weight atau gym machine dapat dilakukan sesuai dengan tujuan, tingkat kebugaran, status cedera, dan pengalaman (Parrish, 2014). Bagi para pemula, mesin merupakan pilihan karena dapat memberikan keuntungan kekuatan secara nyata, tetapi pada tingkat yang lebih aman. Bagi orang terlatih yang ingin membangun kekuatan yang lebih baik, free weight adalah pilihan terbaik. Meskipun demikian, dalam memiliki program yang efektif, pengguna dapat mengombinasikan antara free weight dan gym machine. 
Memperhatikan peranan kekuatan yang sangat strategis tersebut, bisa dimengerti bahwa latihan kekuatan seolah menjadi kebutuhan bagi masyarakat kelas menengah, mahasiswa, dan para atlet. Dari pengamatan penulis di Lembah Fitness Centre, sebagian besar anggota adalah mahasiswa, mencapai lebih $80 \%$ dari total anggota. Demikian juga dengan fitness centre yang dikelola oleh FIK, sebagain besar adalah para mahasiswa. Ironisnya sebagian besar anggotanya adalah mahasiswa non-FIK. Hal ini bisa dimengerti karena mahasiswa FIK telah mendapatkan kuliah praktik olahraga relatif memadai sehingga kurang berminat dalam olahraga di gym. Jika ditinjau dari pentingnya aspek biomotor kekuatan, mestinya sudah menjadi keharusan bagi mahasiswa FIK untuk terlibat dalam latihan di fitness centre.

Dari laporan instruktur Lembah Fitness ditunjukkan bahwa sebagian besar anggota lebih menikmati latihan upper body daripada lower body. Berkaitan dengan itu pihak pengelola juga lebih banyak menyediakan peralatan yang digunakan untuk tujuan tersebut seperti, dumbell press, bench press, shulder press, one hand curl, double arm curl, tricep extension, pull down, shoulder shrug, cable cross over, chinning, diping, dan rowing. Lebih daripada itu, beberapa peralatan tersebut disediakan lebih dari satu unit. Di sisi lain, peralatan untuk pengembangan lower body hanya terbatas pada leg extension, leg curl, leg press, dan squat, bahkan beberapa fitness centre hanya menyediakan satu unit peralatan termaksud. Squat merupakan jenis latihan kekuatan otot kaki yang melibatkan beberapa persendian, dari cervicalis, veterbrae, lumbalis, knee, enkle sampai metatartal. Latihan yang banyak melibatkan banyak persendian akan mengerahkan lebih banyak kelompok otot.

Seperti telah dikemukan bahwa pengembangan kekuatan dan hypertrophy otot dapat dilakukan dengan gym machine dan free weight. Latihan menggunakan gym machine secara biomekanika melibatkan gerakan vertikal yang dikontrol oleh machine yang berada di kanan dan kiri sehingga mudah dan aman digunakan. Di sisi lain, latihan menggunakan free weight secara biomekanika melibatkan gerakan yang arahnya sama seperti gym machine, akan tetapi tidak ada bantuan penyeimbang baik di kiri maupun kanan sehingga pengguna harus mempertahankan keseimbangan dalam mengeksekusi gerakan vertikal tersebut. Karena eksekusi gerakannya sama, ini akan melibatkan kontraksi kelompok otot yang sama sehingga akan mempunyai efek terhadap peningkatan kekuatan otot yang sama pula. Meskipun demikian, karena free weight melibatkan lingkup gerak yang sama dan juga harus mempertahankan keseimbangan, itu akan memengaruhi peningkatan biomotor yang lain seperti power, kelincahan, kecepatan, kelentukan, dan hypertrophy otot.

Oleh karena luasnya pengaruh dari pelatihan squat menggunakan free weight dan gym machine, penulis membatasi kajian ini hanya pada biomotor kekuatan, power, dan hypertrophy otot. Berdasarkan hal tersebut, penelitian ini bertujuan untuk menguji pengaruh latihan squat menggunakan free weight dan gym machine terhadap kekuatan, power, dan hypertrophy otot; dan menguji perbedaan pengaruh latihan squat menggunakan free weight dan gym machine terhadap kekuatan, power, dan hypertrophy otot.

\section{METODE}

Desain Penelitian yang digunakan dalam penelitian ini adalah eksperimen semu. Metode ini bersifat menguji pengaruh satu atau lebih variabel terhadap variabel lain. Menurut Arikunto (2010, p.207), penelitian eksperimen merupakan penelitian yang dimaksudkan untuk mengetahui ada tidaknya akibat dari sesuatu yang dikenakan pada subjek selidik. Desain penelitian ini adalah two group pretest-postest design.

Penelitian ini dilaksanakan di Lembah Fitness UGM Yogyakarta. Waktu penelitian pada bulan Maret sampai dengan April. Populasi dalam penelitian ini adalah mahasiswa semester II Jurusan Pendidikan Kepelatihan Olahraga (PKO) kelas B, Fakultas Ilmu Keolahragaan (FIK), Universitas Negeri Yogyakarta (UNY), tahun akademik 2015, umur 19 sampai dengan 20 tahun yang terdiri atas 37 orang laki-laki.

Sampel dalam penelitian ini dipilih berdasarkan teknik simple random sampling berjumlah 32 orang. Seluruh sampel tersebut dikenai pretest kekuatan, power, dan pengukuran hypertrophy otot untuk menentukan kelompok treatment, diranking nilai pretestnya, kemudian dipasangkan (matched) dengan pola A-B-B-A dalam dua kelompok dengan anggota masing-masing 16 orang. Sampel dibagi menjadi dua kelompok: kelompok A diberi perlakuan latihan squat menggunakan free weight, kelompok B dengan latihan squat menggunakan gym machine.

Latihan squat menggunakan free weight sebagai latihan dengan gerakan menekuk lutut dan meluruskan kembali pada posisi tegak dengan beban tertentu dengan tujuan meningkatkan kekuatan dan pengondisian dengan meng- 
gunakan free weight. Latihan squat menggunakan gym machine sebagai latihan dengan gerakan menekuk lutut dan meluruskan kembali pada posisi tegak dengan beban tertentu dengan tujuan meningkatkan kekuatan dan pengondisian dengan menggunakan gym machine. Kekuatan merupakan kemampuan otot atau sekelompok otot untuk berkontraksi baik isotonik, isometrik, eksentrik, dan isokinetik dengan tujuan membangkitkan ketegangan terhadap suatu ketahanan dalam satu kerja yang diukur dengan back and leg dynamometer. Power adalah kemampuan otot untuk menggerakan daya dengan maksimal dalam waktu yang sangat singkat yang diukur dengan JDF. Hypertrophy otot adalah akibat dari peningkatan jumlah filamen aktin dan miosin dalam setiap serabut otot yang diukur dengan pita pengukur dan skinfold.

Untuk menguji normalitas data digunakan Kolmogorov Smirnov. Kriteria pengujiannya, apabila signifikansi harga statistik hitung lebih besar dari $\alpha=0,05$ (5\%), distribusi datanya adalah normal. Untuk menghitung uji homogenitas data digunakan rumus uji Levene Test. Kriteria pengujiannya, apabila signifikansi harga statistik hitung lebih besar dari $\alpha=0,05$ (5\%), varians datanya adalah homogen. Teknik analisis data yang digunakan adalah uji-F dengan menggunakan bantuan program SPSS 16.

\section{HASIL DAN PEMBAHASAN}

Deskriptif Statistik

Deskriptif statistik kelompok latihan squat menggunakan free weight disajikan pada Tabel 1.

Tabel 1. Deskriptif Statistik Kelompok Latihan Squat Menggunakan Free Weight

\begin{tabular}{lrrrrrrr}
\hline Statisti & \multicolumn{2}{c}{ Kekuatan } & \multicolumn{2}{c}{ Power } & \multicolumn{2}{c}{ Hypertrophy } \\
\cline { 2 - 6 } k & \multicolumn{1}{c}{ Pre } & Post & & Pre & Post & Pre & \multicolumn{1}{c}{ Post } \\
\hline N & 16 & 16 & 16 & 16 & 16 & 16 \\
Mean & 221, & 279,56 & 53,50 & 58,25 & 49,21 & 51,66 \\
Sd & 46,23 & 27,731 & 6,250 & 5,744 & 3,314 & 3,592 \\
Min & 155,0 & 216,00 & 44,00 & 50,00 & 45,20 & 47,60 \\
Max & 290,0 & 300,00 & 69,00 & 71,00 & 57,75 & 60,25 \\
Sum & 3536, & 4473,0 & 856,0 & 932,0 & 787,3 & 826,55 \\
\hline
\end{tabular}

Deskriptif statistik kelompok latihan squat menggunakan gym machine disajikan dalam Tabel 2.

Hasil Uji Normalitas
Hasil uji normalitas disajikan dalam dalam Tabel 3. Dari hasil Tabel 3 dapat dilihat bahwa semua data memiliki nilai p (Sig.) $>0,05$, berarti variabel berdistribusi normal.

Hasil uji homogenitas penelitian ini dapat dilihat pada Tabel 4.

Tabel 2. Deskriptif Statistik Kelompok Latihan

Squat Menggunakan Gym Machine

\begin{tabular}{ccccccc}
\hline Statisti & \multicolumn{2}{c}{ Kekuatan } & \multicolumn{2}{c}{ Power } & \multicolumn{3}{c}{ Hypertrophy } \\
\cline { 2 - 7 } k & Pre & Post & Pre & Post & Pre & Post \\
\hline N & 16 & 16 & 16 & 16 & 16 & 16 \\
Mean & 225,25 & 254,37 & 53,25 & 55,68 & 49,77 & 50,56 \\
Sd & 48,462 & 38,954 & 4,524 & 4,541 & 3,685 & 3,592 \\
Min & 155,0 & 178,00 & 42,00 & 43,00 & 41,20 & 41,95 \\
Max & 295,0 & 300,00 & 61,00 & 63,00 & 54,10 & 54,90 \\
Sum & 3604,0 & 4070,0 & 852,0 & 891,0 & 796,35 & 808,95 \\
\hline
\end{tabular}

Tabel 3. Hasil Uji Normalitas

\begin{tabular}{|c|c|c|c|}
\hline Kelompok & $\mathrm{p}$ & Sig. & Keterangan \\
\hline \multicolumn{4}{|c|}{ Kelompok Free Weight } \\
\hline Pretest Kekuatan & 0,636 & 0,05 & Normal \\
\hline Posttest Kekuatan & 0,363 & 0,05 & Normal \\
\hline Pretest Power & 0,834 & 0,05 & Normal \\
\hline Posttest Power & 0,943 & 0,05 & Normal \\
\hline $\begin{array}{l}\text { Pretest } \\
\text { Hypertrophy }\end{array}$ & 0,680 & 0,05 & Normal \\
\hline $\begin{array}{l}\text { Posttest } \\
\text { Hypertrophy }\end{array}$ & 0,882 & 0,05 & Normal \\
\hline \multicolumn{4}{|c|}{ Kelompok Gym Machine } \\
\hline Pretest Kekuatan & 0,563 & 0,05 & Normal \\
\hline Posttest Kekuatan & 0,745 & 0,05 & Normal \\
\hline Pretest Power & 0,907 & 0,05 & Normal \\
\hline Posttest Power & 0,760 & 0,05 & Normal \\
\hline $\begin{array}{l}\text { Pretest } \\
\text { Hypertrophy }\end{array}$ & 0,766 & 0,05 & Normal \\
\hline $\begin{array}{l}\text { Posttest } \\
\text { Hypertrophy }\end{array}$ & 0,851 & 0,05 & Normal \\
\hline
\end{tabular}

Tabel 4. Hasil Uji Homogenitas

\begin{tabular}{|c|c|c|c|c|}
\hline Kelompok & df1 & df2 & Sig, & Keterangan \\
\hline \multicolumn{5}{|c|}{ Kelompok Free Weight } \\
\hline Pre-pos Kekuatan & 1 & 30 & 0,111 & Homogen \\
\hline Pre-pos Power & 1 & 30 & 0,755 & Homogen \\
\hline $\begin{array}{l}\text { Pre-pos } \\
\text { Hypertrophy }\end{array}$ & 1 & 30 & 0,755 & Homogen \\
\hline \multicolumn{5}{|c|}{ Kelompok Gym Machine } \\
\hline Pre-pos Kekuatan & 1 & 30 & 0,136 & Homogen \\
\hline Pre-pos Power & 1 & 30 & 0,845 & Homogen \\
\hline $\begin{array}{l}\text { Pre-pos } \\
\text { Hypertrophy }\end{array}$ & 1 & 30 & 0,878 & Homogen \\
\hline
\end{tabular}

Dari Tabel 4 dapat dilihat nilai pretestposttest sig. $\mathrm{p}>0,05$, artinya data bersifat homogen. 
Jurnal Keolahragaan 6 (2), 2018 - 156

Lia Karina Mansur, Joko Pekik Irianto, Mansur Mansur

Tabel 5. Uji-F Hasil Pretest dan Posttest Kelompok Latihan Squat Menggunakan Free Weight

\begin{tabular}{lrccccc}
\hline \multicolumn{1}{c}{ Variabel } & \multicolumn{1}{c}{ Mean } & $\mathrm{F}_{\mathrm{ht}}$ & $\mathrm{F}_{\mathrm{tb}}$ & Sig, & Selisih & $\%$ \\
\hline Kekuatan & 221,00 & \multirow{2}{*}{18,880} & 4,543 & 0,000 & 58,5625 & $26,49 \%$ \\
Power & 279,56 & & & & & \\
& 53,50 & 5,009 & 4,543 & 0,033 & 4,75 & $8,89 \%$ \\
Hypertrophy & 58,25 & & & & \\
& 49,21 & \multirow{2}{*}{6,510} & 4,543 & 0,028 & 2,45 & $4,97 \%$ \\
\hline
\end{tabular}

Tabel 6. Uji-F Hasil Pretest dan Posttest Kelompok Latihan Squat Menggunakan Gym Machine.

\begin{tabular}{|c|c|c|c|c|c|c|}
\hline Variabel & Mean & $\mathrm{F}_{\mathrm{ht}}$ & $\mathrm{F}_{\mathrm{tb}}$ & Sig, & Selisih & $\%$ \\
\hline Kekuatan & $\begin{array}{l}225,25 \\
254,38\end{array}$ & 14,600 & 4,543 & 0,042 & 29,125 & $12,93 \%$ \\
\hline Power & $\begin{array}{l}53,2500 \\
55,6875\end{array}$ & 5,64 & 4,543 & 0,000 & 2,4327 & $4,57 \%$ \\
\hline Hypertrophy & $\begin{array}{l}49,77 \\
50,56\end{array}$ & 4,754 & 4,543 & 0,000 & 0,79 & $1,58 \%$ \\
\hline
\end{tabular}

Tabel 7. Uji-F Hasil Kelompok Free Weight dan Kelompok Gym Machine

\begin{tabular}{ccccccc}
\hline Variabel & Mean & $\mathbf{F}_{\text {ht }}$ & $\mathbf{F}_{\text {tb }}$ & Sig, & Selisih & $\%$ \\
\hline \multirow{2}{*}{ Kekuatan } & 58,5625 & 4,730 & 4,543 & 0,038 & 29,43750 & $26,49 \%$ \\
& 29,1250 & & & & & $12,93 \%$ \\
Power & 4,7500 & 6,202 & 4,543 & 0,019 & 2,31250 & $8,89 \%$ \\
& 2,4375 & & & & & $4,57 \%$ \\
Hypertrophy & 2,45 & 78,659 & 4,543 & 0,00 & 1,66 & $4,97 \%$
\end{tabular}

Kelompok Latihan Squat Menggunakan Free Weight

Hipotesis yang pertama yaitu untuk menguji adakah pengaruh latihan squat menggunakan free weight terhadap kekuatan, power, dan hypertrophy. Kesimpulan penelitian dinyatakan signifikan jika nilai $\mathrm{F}$ hitung $>\mathrm{F}$ tabel dan nilai sig lebih kecil dari 0.05 (Sig < 0.05). Berdasarkan hasil analisis diperoleh data seperti pada Tabel 5

Berdasarkan hasil uji-F pada Tabel 5 di atas, dapat dilihat bahwa $\mathrm{F}$ hitung dan $\mathrm{F}$ tabel (df 15) 4,543 dengan nilai signifikansi $p$ sebesar 0,000 . Oleh karena F hitung > Ftabel 4,543, dan nilai signifikansi $0,000<0,05$, hasil ini menunjukkan terdapat perbedaan yang signifikan. Dengan demikian hipotesis yang menyatakan bahwa ada pengaruh yang signifikan latihan squat menggunakan free weight terhadap kekuatan, power, dan hypertrophy, telah terbukti.

Kelompok Latihan Squat Menggunakan Gym Machine

Hipotesis yang kedua yaitu untuk menguji adakah pengaruh latihan squat menggunakan gym machine terhadap kekuatan, power, dan hypertrophy. Kesimpulan penelitian dinyatakan signifikan jika nilai $\mathrm{F}_{\text {hitung }}>\mathrm{F}_{\text {tabel }}$ dan nilai sig lebih kecil dari 0.05 (Sig < 0.05). Berdasarkan hasil analisis diperoleh data pada Tabel 6 .

Berdasarkan hasil uji-t pada Tabel 6, dapat dilihat bahwa $\mathrm{F}_{\text {hitung }}$ dan $\mathrm{F}_{\text {tabel (df 15) }}$ 4,543 dengan nilai signifikansi $\mathrm{p}$ sebesar 0,000 . Oleh karena $\mathrm{F}$ hitung $>F_{\text {tabel }} 4,543$, dan nilai signifikansi 0,000 < 0,05 , hasil ini menunjukkan terdapat perbedaan yang signifikan. Dengan demikian hipotesis yang menyatakan bahwa ada pengaruh yang signifikan latihan squat menggunakan gym machine terhadap kekuatan, power, dan hypertrophy, telah terbukti.

Perbedaan Kelompok Latihan Squat Menggunakan Free Weight dan Latihan Squat Menggunakan Gym Machine

Hipotesis yang ketiga yaitu untuk menguji adakah perbedaan pengaruh latihan squat menggunakan free weight dan latihan squat menggunakan gym machine terhadap kekuatan, power, dan hypertrophy. Kesimpulan penelitian dinyatakan signifikan jika nilai $\mathrm{F}_{\text {hitung }}>\mathrm{F}_{\text {tabel }}$ dan nilai sig lebih kecil dari 0.05 (Sig < 0.05). Berdasarkan hasil analisis diperoleh data pada Tabel 7.

Berdasarkan hasil uji-F pada Tabel 7, dapat dilihat bahwa $\mathrm{F}$ hitung dan $\mathrm{F}$ tabel (df 15) 4,543 dengan nilai signifikansi $\mathrm{p}$ sebesar 0,000 . Oleh karena $\mathrm{F}_{\text {hitung }}>\mathrm{F}_{\text {tabel }} 4,543$, dan nilai signifikansi $0,000<0,05$, hasil ini menunjukkan terdapat 
Jurnal Keolahragaan 6 (2), 2018 - 157

Lia Karina Mansur, Joko Pekik Irianto, Mansur Mansur

perbedaan yang signifikan antara latihan squat menggunakan free weight dan latihan squat menggunakan gym machine terhadap kekuatan, power, dan hypertrophy. Hasil tersebut, menunjukkan bahwa rata-rata data kekuatan, power, dan hypertrophy kelompok latihan squat menggunakan free weight lebih baik daripada kelompok latihan squat menggunakan gym machine.

\section{Pembahasan}

Hasil menunjukkan bahwa ada pengaruh latihan squat menggunakan free weight dan latihan squat menggunakan gym machine terhadap kekuatan, power, dan hypertrophy otot. Hasil penelitian selengkapnya dijelaskan sebagai berikut.

Pengaruh Latihan Squat Menggunakan Free Weight terhadap Kekuatan, Power, dan Hypertrophy

Berdasarkan hasil penelitian yang telah dilakukan menunjukkan bahwa ada perbedaan antara rerata pretest dan posttest, sehingga dapat dikatakan bahwa kekuatan otot tungkai peserta tes mengalami peningkatan signifikan yang ditunjukkan dengan perbedaan rerata yaitu 221,00 menjadi 279,56. Peningkatan hasil pada penelitian ini dapat dilihat apabila dihitung selisih antara rerata pretest dan posttest yaitu 58,5625. Jadi dapat disimpulkan bahwa latihan squat menggunakan free weight dapat meningkatkan kekuatan otot tungkai sebesar 26,49\%. Power otot tungkai peserta tes mengalami peningkatan signifikan yang ditunjukkan dengan perbedaan rerata yaitu 53,5000 menjadi 58,2500. Peningkatan hasil pada penelitian ini dapat dilihat apabila dihitung selisih antara rerata pretest dan posttest yaitu 4,75. Jadi dapat disimpulkan bahwa latihan squat menggunakan free weight dapat meningkatkan power otot tungkai sebesar 8,89\%.

Kekuatan merupakan kemampuan otot atau sekelompok otot untuk berkontraksi baik isotonik, isometrik, eksentrik dan isokinetik dengan tujuan membangkitkan ketegangan terhadap suatu ketahanan dalam satu kerja.Seiring terjadinya adaptasi secara fisiologis, latihan beban juga menyebabkan adaptasi pada beberapa unsur fisik. Latihan beban selain membangun kekuatan, juga dapat meningkatkan kemampuan unsur-unsur kondisi fisik lain. Peningkatan kemampuan kerja otot akibat latihan beban ini disebabkan oleh perubahan fisiologis yang terjadi pada system neuromuscular (adaptation system neuro-muscular).
Peningkatan ukuran otot menyebabkan kontraksi otot lebih kuat (power meningkat), pengulangan kontraksi lebih cepat (meningkatkan speed), periode latihan tahan lama (meningkatkan ketahanan otot). Latihan squat diresepkan untuk atlet dan nonatlet untuk mengembangkan kekuatan tubuh bagian bawah (DeForest, Cantrell, \& Schilling, 2014, p.302). Latihan kekuatan selain bertujuan meningkatkan kekuatan, terdapat tujuan lain yaitu meningkatnya ukuran besarnya serabut otot yang disebut dengan serabut otot. Periodisasi latihan menentukan sasaran dan jumlah macam latihan. Hasil ini senada dengan penelitian yang dilakukan oleh Wirth, Keiner, Hartmann, Sander, \& Mickel (2016, p.202) bahwa latihan kekuatan menggunakan barbel squat yang diberikan kepada 60 orang laki-laki dalam waktu 8 minggu dengan 2 sesi per minggu menunjukkan ada peningkatan yang signifikan kekuatan otot tungkai. Hal ini tampak lebih mudah bagi SSP untuk menransfer aktivasi tingkat tinggi.

Selain itu, perubahan kelompok LP tidak mencapai signifikan karena kenaikan kekuatan dinamis maksimumnya tinggi. Oleh karena itu, diharapkan dapat menemukan setidaknya beberapa transfer kemampuan ditingkatkan untuk mengaktifkan otot-otot di SJ dan CMJ. Hal ini sejalan dengan penelitian yang dilakukan oleh Furqon dan Doewes (2002), latihan untuk meningkatkan daya ledak otot dilakukan selama 6 minggu, 3 kali dalam seminggu, jumlah pengulangan 8-12 kali, jumlah set 3-5 set, dan istirahat antarset 2 menit.

Hypertrophy otot peserta tes mengalami peningkatan signifikan yang ditunjukkan dengan perbedaan rerata yaitu 49,21 menjadi 51,66. Peningkatan hasil pada penelitian ini dapat dilihat apabila dihitung selisih antara rerata pretest dan posttest yaitu 2,45. Jadi dapat disimpulkan bahwa latihan squat menggunakan free weight dapat meningkatkan ukuran serabut otot (hypertrophy) sebesar 4,97\%.

Hypertrphy otot adalah akibat dari peningkatan jumlah filamen aktin dan miosin dalam setiap serabut otot. Sasaran kekuatan pada periode persiapan dimana latihan ditujukan untuk meningkatkan kelompok otot-otot besar seperti tungkai. Selanjutnya, pada periode persiapan tahap kedua sasaran latihan kekuatan adalah kekuatan maksimal yang diteruskan dengan power (Sukadiyanto \& Muluk, 2011, p.104). Lebih lanjut Fleck, (2014, p.28) berpendapat bahwa periodesasi berpengaruh pada meningkatnya kekuatan dan hypertrophy otot. Latihan 
beban dapat dilakukan dengan menggunakan beban luar yaitu beban bebas (free weight) seperti dumbell barbell sangatlah banyak dan bervariasi sesuai dengan tujuan latihan serta perkenaan ototnya. Kerusakan otot lokal yang disebabkan oleh pelatihan beban juga telah terlibat dalam memediasi pertumbuhan otot (Evans, 2002, p.217). Lebih lanjut, Norrbrand, Fluckey, Pozzo, \& Tesch (2008, p.277) mengatakan latihan eksentrik menghasilkan keuntungan yang lebih besar pada otot tanpa lemak dibandingkan kontraksi konsentris dan isometrik. Hal tersebut akan memicu hypertrophy otot maksimal dalam menanggapi latihan resistensi tidak tercapai kecuali tindakan otot eksentrik dilakukan. Program latihan yang menggunakan beban pemberat di luar tubuh (weight training) akan mempercepat proses terjadinya hypertrophy pada otot (Sukadiyanto \& Muluk, 2011, p.101). Dari hasil analisis dapat disarikan bahwa latihan squat menggunakan free weight efektif untuk meningkatkan kekuatan, power, dan hypertrophy otot.

Pengaruh Latihan Squat Menggunakan Gym Machine terhadap Kekuatan, Power, dan Hypertrophy

Hasil penelitian menunjukkan bahwa ada pengaruh latihan squat menggunakan gym machine terhadap kekuatan, power, dan hypertrophy otot. Dilihat dari tiap-tiap variabel bahwa ada perbedaan antara rerata pretest dan posttest, sehingga dapat dikatakan bahwa kekuatan otot tungkai peserta tes mengalami peningkatan signifikan yang ditunjukkan dengan perbedaan rerata yaitu 225,25 menjadi 254,38 . Peningkatan hasil pada penelitian ini dapat dilihat apabila dihitung selisih antara rerata pretest dan posttest yaitu 29,125. Jadi dapat disimpulkan bahwa latihan squat menggunakan gym machine dapat meningkatkan kekuatan otot tungkai sebesar $12,93 \%$. Power otot tungkai peserta tes mengalami peningkatan signifikan yang ditunjukkan dengan perbedaan rerata yaitu 53,2500 menjadi 55,6875. Peningkatan hasil pada penelitian ini dapat dilihat apabila dihitung selisih antara rerata pretest dan posttest yaitu 2,4327. Jadi dapat disimpulkan bahwa latihan squat menggunakan gym machine dapat meningkatkan kekuatan otot tungkai sebesar $4,57 \%$. Gym machine yaitu peralatan beban yang terdiri atas berbagai stasiun yang terletak pada satu rangka besar, dan lebih mudah dalam mengurangi atau menambah beban karena hanya tinggal memasukkan pen pengunci beban pada tempatnya.
Harsono (2010, p.3) berpendapat bahwa latihan adalah pemberian rangsangan, yang akan menyebabkan organ tubuh mengadakan penyesuaian atau kompensasi. Latihan selama 6 minggu dengan frekuensi latihan 3 kali dalam 1 minggu sangat berpengaruh terhadap peningkatan daya ledak otot tungkai. Ini sesuai dengan pendapat Panoelar (Santosa, 2015, p.5), "pelatihan dalam 1 minggu dengan frekuensi 3 kali lebih kecil kemungkinan cedera dan ada kenaikan atau peningkatan kapasitas fungsional."

Hypertrophy otot peserta tes mengalami peningkatan signifikan yang ditunjukkan dengan perbedaan rerata yaitu 49,77 menjadi 50,56. Peningkatan hasil pada penelitian ini dapat dilihat apabila dihitung selisih antara rerata pretest dan posttest yaitu 0,79 . Jadi dapat disimpulkan bahwa latihan squat menggunakan gym machine dapat meningkatkan ukuran serabut otot (hypertrophy) sebesar $1,58 \%$. Periodesasi latihan menentukan sasaran dan jumlah macam latihan. Sasaran kekuatan pada periode persiapan latihan ditujukan untuk meningkatkan kelompok otot-otot besar seperti tungkai. Selanjutnya, pada periode persiapan tahap kedua sasaran latihan kekuatan adalah kekuatan maksimal yang diteruskan dengan power (Sukadiyanto \& Muluk, 2011, p.104). Lebih lanjut, Fleck, (2014, p.28) berpendapat bahwa periodesasi berpengaruh pada meningkatnya kekuatan dan hypertrophy otot.

Tekanan mekanik mungkin merupakan mediator hipertrofi otot yang paling dominan (Goldspink, 2002; Hornberger \& Chien, 2006; Vierck, et.al., 2000). Dari hasil analisis dapat disarikan bahwa latihan squat menggunakan gym machine efektif untuk meningkatkan kekuatan, power, dan hypertrophy otot.

Perbedaan Pengaruh Latihan Squat Menggunakan Free Weight dan Latihan Squat Menggunakan Gym Machine terhadap Kekuatan, Power, dan Hypertrophy

Hasil penelitian menunjukkan bahwa ada perbedaan pengaruh latihan squat menggunakan free weight dan gym machine terhadap kekuatan, power, dan hypertrophy. Dilihat dari hasil persentase kenaikan nilai antara pretest dan posttest ditunjukkan kenaikan persentase pada kelompok latihan squat menggunakan free weight lebih tinggi daripada latihan squat menggunakan gym machine terhadap kekuatan, power, dan hypertrophy. Latihan squat menggunakan free weight lebih baik daripada latihan gym machine terhadap kekuatan, power, dan hypertrophy. 
Latihan squat menggunakan free weight sebagai latihan dengan gerakan menekuk lutut dan meluruskan kembali pada posisi tegak dengan beban tertentu dengan tujuan meningkatkan kekuatan dan pengondisian dengan menggunakan free weight. Di sisi lain, latihan squat menggunakan gym machine sebagai latihan dengan gerakan menekuk lutut dan meluruskan kembali pada posisi tegak dengan beban tertentu dengan tujuan meningkatkan kekuatan dan pengondisian dengan menggunakan gym machine. Latihan squat menggunakan free weight dan gym machine memiliki sifat sebagai berikut: (a) keduanya memberikan beberapa bentuk ketahanan, (b) keduanya memungkinkan rentang gerak bebas, (c) keduanya memungkinkan kecepatan gerakan yang bervariasi, dan (d) keduanya memungkinkan resistensi progresif. Keempat sifat ini sangat penting untuk manfaat yang ditawarkan oleh program pelatihan beban yang efektif. Meskipun ada kemiripan antara resistensi gym machine dan free weight, orang akan berasumsi bahwa free weight lebih baik.

Free weight memiliki keuntungan antara lain: (a) sering digunakan untuk latihan yang meningkatkan sebagian besar otot tubuh baik secara langsung maupun untuk dukungan dan stabilisasi,(b) meminjamkan diri mereka untuk balistik atau "eksploitasi" latihan, (c) dapat dengan mudah digunakan untuk mensimulasikan dunia nyata mengangkat gerakan, (d) melibatkan rentang gerak dan pengaktifan otot mirip dengan yang ada di banyak gerakan olahraga khususnya untuk bagian bawah tubuh, dan (e) rendah biaya (Haff, 2000, p.18). Lebih lanjut, penelitian ini senada dengan penelitian yang dilakukan oleh Cotterman, Darby, \& Skelly, (2005, p.169) bahwa latihan squat dengan free weight lebih efektif atau mempunyai pengaruh lebih besar daripada latihan squat menggunakan gym machine. Hal ini dibuktikan juga oleh Wirth, et al (2016, p.208) dalam penelitiannya yang membandingkan latihan kekuatan dengan menggunakan free weight berupa barbell squat dan gym machine berupa leg press diberikan kepada 120 orang laki-laki dalam waktu 8 minggu dengan 2 sesi per minggu menunjukkan ada peningkatan yang signifikan kekuatan otot tungkai. Dari dua jenis latihan tersebut latihan kekuatan dengan menggunakan free weight berupa barbell squat lebih unggul dibandingkan latihan kekuatan dengan menggunakan gym machine berupa leg press. Karena perbedaan antara kedua kelompok pelatihan juga signifikan secara statistik, dapat disimpulkan bahwa pelatihan menggunakan barbell squat lebih unggul daripada tekanan kaki (mengenai peningkatan kinerja lompatan). Mungkin, manfaat lebih besar dari barbell squat adalah posisi tubuh lebih sesuai dengan lompatan yang diuji. Kesamaan jongkok dan SJ/CMJ cenderung memudahkan pengalihan kinerja meningkat. Oleh karena itu, tampaknya lebih mudah bagi SSP untuk menransfer aktivasi tingkat tinggi antara ketiga tugas motor ini dibandingkan dengan tekanan kaki. Selain itu, masih mengherankan bahwa perubahan kelompok LP tidak mencapai signifikan karena kenaikan kekuatan dinamis maksimumnya tinggi. Oleh karena itu, diharapkan dapat menemukan setidaknya beberapa transfer kemampuan ditingkatkan untuk mengaktifkan otot-otot di SJ dan CMJ.

Pengaruh latihan squat dengan menggunakan gym machine dan free weight dalam penelitian dilihat dari faktor pembebanan menunjukkan ada peningkatan yang signifikan terhadap pertumbuhan serabut otot (hypertrophy otot), dalam pembebanan faktor penting adalah memberikan beban yang cukup pada otot yang dirangsang untuk tumbuh. Hasil menunjukkan bahwa hasil latihan squat dengan menggunakan free weight lebih efektif dibandingkan dengan hasil latihan squat dengan menggunakan gym machine. Hal ini terlihat dari ciri pembebanan dari kedua metode tersebut, latihan squat dengan menggunakan free weight melibatkan bentuk bebas yang mengharuskan seseorang menggunakan lebih banyak otot (Clayton, et.al., 2015, p.6). Sebagai contoh squat dengan menggunakan barbel menuntut untuk menyeimbangkan diri (agar tidak jatuh) dan dengan demikian lebih banyak membutuhkan aktivasi otot daripada latihan squat dengan meng-gunakan gym machine. Selain itu, peningkatan kepadatan mineral tulang juga terjadi terbukti lebih besar dengan latihan squat dengan menggunakan free weight.

Temuan lain juga diungkapkan oleh Schwanbeck (2008, p.44) dalam penelitiannya yang menguji pengaruh latihan dengan free weight dan gym machine pada massa otot, kekuatan dan kadar testoteron dan kortisol yang diberikan kepada 15 orang laki-laki dan 21 perempuan yang dilatihkan selama 8 minggu. Kedua jenis latihan ini menunjukkan peningkatan tanpa perbedaan antarkelompok. Hasil penelitian menunjukkan latihan free weight lebih unggul atau mengalami peningkatan lebih besar dibandingkan dengan latihan dengan menggunakan gym machine dalam meningkatkan massa otot, kekuatan, dan kadar testoteron dan kortisol. 
Hal ini dapat disarikan bahwa latihan squat menggunakan free weight lebih tinggi daripada latihan squat menggunakan gym machine terhadap kekuatan, power, dan hypertrophy.

\section{SIMPULAN}

Berdasarkan hasil penelitian dan hasil analisis data yang telah dilakukan, diperoleh kesimpulan sebagai berikut: (1) ada pengaruh latihan squat menggunakan free weight terhadap kekuatan, power, dan hypertrophy otot, (2) ada pengaruh latihan squat menggunakan gym machine terhadap kekuatan, power, dan hypertrophy otot, (3) ada perbedaan pengaruh latihan squat menggunakan free weight dan latihan squat menggunakan gym machine terhadap kekuatan, power, dan hypertrophy otot. Berdasarkan persentase kenaikan nilai pretest dan posttest kekuatan, power, dan hypertrophy otot, kelompok latihan squat menggunakan free weight lebih baik daripada kelompk latihan squat menggunakan gym machine.

\section{DAFTAR PUSTAKA}

Archer, D. C., Brown, L. E., Coburn, J. W., Galpin, A. J., Drouet, P. C., Leyva, W. D., ... \& Wong, M. A. (2016). Effects of shortterm jump squat training with and without chains on strength and power in recreational lifters. International Journal of Kinesiology and Sports Science, 4(4), 18-24.

Arikunto, S. (2010). Prosedur penelitian: Suatu pendekatan praktik. Edisi Revisi. Jakarta: Rineka Cipta.

Bompa, T. O., \& Haff, G. (2009). Periodization: Theory and methodology of training. Human Kinetics.

Bompa, T., \& Buzzichelli, C. (2015). Periodization training for sports. Human kinetics.

Chandler, T.J., \& Brown, L.E. (2008). Conditioning for strength and human performance. Philadelphia: Williams \& Wilkins.

Cotterman, M. L., Darby, L. A., \& Skelly, W. A. (2005). Comparison of muscle force production using the Smith machine and free weights for bench press and squat exercises. The Journal of Strength \& Conditioning Research, 19(1), 169-176.

DeForest, B. A., Cantrell, G. S., \& Schilling, B. K. (2014). Muscle activity in single-vs. double-leg squats. International Journal of Exercise Science, 7(4), 302.

Evans, W.J. (2002). Effects of exercise on senescent muscle. Clinical Orthopaedics and Related Research, 403(Suppl), S21120.

Fleck, S. J. (2014). Optimizing periodezation of strength training for maximal gains and hypertrophy. Journal Sport \& Exercise Science, 2

Goldspink, G. (2002). Gene expression in skeletal muscle. Biochemical Society Transactions, 30(2), 285-290.

Haff, G.G. (2000). Rountable discussion machines versus free weights. National Strength \& Condition Association, 22(6), 18-30.

Harsono. (2010). Latihan kondisi fisik. Jakarta: Depdikbud Dirjen Dikti PPLTK.

Hornberger, T. A., \& Chien, S. (2006). Mechanical stimuli and nutrients regulate rapamycin-sensitive signaling through distinct mechanisms in skeletal muscle. Journal of cellular biochemistry, 97(6), 1207-1216.

Furqon, H., \& Doewes, M. (2002). Pliometrik Untuk meningkatkan power. Surakarta: Program Pasca Sarjana Universitas Sebelas Maret.

Ismoko, A., \& Sukoco, P. (2013). Pengaruh metode latihan dan koordinasi terhadap power tungkai atlet bola voli junior putri. Jurnal Keolahragaan, 1(1), 1 - 12. doi:https://doi.org/10.21831/jk.v1i1.2339

Karyono, T. (2011). Pengaruh metode latihan dan power otot tungkai terhadap kelincahan bulutangkis. Tesis magister, Tidak diterbitkan, Universitas Sebelas Maret Surakarta, Surakarta.

Lin, C. W. C., Hiller, C. E., \& de Bie, R. A. (2010). Evidence-based treatment for ankle injuries: a clinical perspective. Journal of Manual \& Manipulative Therapy, 18(1), 22-28.

Norrbrand, L., Fluckey, J. D., Pozzo, M., \& Tesch, P. A. (2008). Resistance training using eccentric overload induces early adaptations in skeletal muscle size. European Journal of Applied Physiology, 102(3), 271-281.

Clayton, N., Drake, J., Larkin, S., Linkul, R., Martino, M., Nutting, M., \& Tumminello, 


\section{Jurnal Keolahragaan 6 (2), 2018 - 161}

Lia Karina Mansur, Joko Pekik Irianto, Mansur Mansur

N. (2015). Foundations of Fitness Programming. Colorado Springs, CO: National Strength and Conditioning Association.

Parrish, A. (2014). Free weight versus machine. MacEwan University

Santosa, D.W. (2015). Pengaruh pelatihan squat jump dengan metode interval pendek terhadap daya ledak (power) otot kaki. Jurnal Kesehatan Olahraga, 3(1), 158164.

Schoenfeld, B. J. (2010). Squatting kinematics and kinetics and their application to exercise performance. The Journal of Strength \& Conditioning Research, 24(12), 3497-3506.

Schwanbeck, S.R. (2008). The effect of training with free weights or machines on muscle mass, strength, and testoterone and cortisol levels. Tesis master, tidak diterbitkan, University of Saskatchewan, Canada.

Singh, A.B. (2012). Sport training. New Delhi: Chawla Offset Printers.
Sucipto, E., \& Widiyanto, W. (2016). Pengaruh latihan beban dan kekuatan otot terhadap hypertrophy otot dan ketebalan lemak. Jurnal Keolahragaan, 4(1), 111-121. doi:https://doi.org/10.21831/jk.v4i1.8131

Suharjana. (2013). Kebugaran jasmani. Yogyakarta: Jogja Global Media.

Sukadiyanto \& Muluk. (2011). Pengantar teori dan metodologi melatih fisik. Bandung: CV Lubuk Agung.

Vierck, J., O'Reilly, B., Hossner, K., Antonio, J., Byrne, K., Bucci, L., \& Dodson, M. (2000). Satellite cell regulation following myotrauma caused by resistance exercise. Cell Biology International, 24(5), 263 272.

Wirth, K., Keiner, M., Hartmann, H., Sander, A., \& Mickel, C. (2016). Effect of 8 weeks of free-weight and machine-based strength training on strength and power performance. Journal of Human Kinetics, 53(1), 201-210.

Zein, M.I. (2013). Cedera anterior cruciate ligament (ACL) pada atlet berusia muda. Medikora, 11(2), 111-121. 